A L - MUDARRIS

Journal of Education

p ISSN: 2620-5831| e ISSN:2620-4355

\title{
PENGENALAN ECO-LITERACY MELALUI MEDIA PEMBELAJARAN DARI SAMPAH DI SEKOLAH DASAR
}

\author{
Shofiyatun Nurlaili*1, Nana Supriatna*2, Sapriya*3 \\ Universitas Pendidikan Indonesia, Bandung, Indonesia \\ Email: 1shofiyatun.nurlaili@upi.edu, 2nanasup@yahoo.com, ${ }^{3}$ ksapriya@yahoo.com
}

\begin{abstract}
Rubbish is one of the biggest environmental problems in Indonesia. The rubbish is not only from households but also from the school environment. If left unchecked, it can cause various diseases that endanger human life. The amount of rubbish is caused by the ignorance of the community towards the environment. Therefore, it is necessary to have eco-literacy that must be inculcated since primary school age. Students who already have an attitude of concern for the environment will try to maintain a sustainable life. Eco-literacy is also needed to process the rubbish into an instructional media that will help the student to understand learning more easily. This study uses literature study methods from several journal articles, books, and other relevant sources. The result of the study shows that learning by instructional media from the rubbish recycling are more concerned about the surrounding environment and easier to understand the learning process in the classroom.

Sampah merupakan salah satu masalah lingkungan yang sangat besar di Indonesia. Sampah bukan hanya berasal dari rumah tangga tetapi juga dari lingkungan sekolah. Jika sampah ini dibiarkan, maka hal itu dapat menyebabkan penyakit. Banyaknya sampah ini juga disebabkan oleh ketidakpedulian masyarakat terhadap lingkungan. Oleh karena itu, eco-literacy harus ditanamkan sejak usia sekolah dasar. Siswa yang sudah memiliki sikap kepedulian terhadap lingkungan, mereka akan berusaha untuk menjaga kehidupan berkelanjutan. Eco-literacy ini juga diperlukan agar siswa mampu mengolah sampah menjadi media pembelajaran sekaligus menjadi modal bagi siswa untuk memahami pembelajaran dengan lebih mudah. Penelitian ini menggunakan metode studi pustaka dari beberapa artikel jurnal, buku, maupun sumber lain yang relevan. Hasil penelitian menunjukkan bahwa pembelajaran dengan menggunakan media daur ulang sampah mengakibatkan siswa lebih peduli terhadap lingkungan sekitarnya dan lebih mudah memahami proses pembelajaran di kelas.
\end{abstract}

Keywords: rubbish, environment, elementary school, eco-literacy, instructional media

\section{A. PENDAhuluan}

Permasalahan lingkungan merupakan salah satu permasalahan yang tidak bisa dihindari. Saat ini, sampah menjadi masalah lingkungan yang sangat serius untuk dihadapi masyarakat Indonesia. Jumlah produksi sampah setiap tahun semakin bertambah seiring dengan bertambahnya jumlah penduduk. Pemerintah telah berupaya dengan berbagai cara untuk mengatasi masalah sampah. Namun, hasilnya masih belum mencapai titik kesempurnaan. Hal ini dikarenakan jumlah sampah yang ada di Indonesia sangat tinggi sehingga pemerintah kesulitan menentukan cara yang tepat untuk menyelesaikannya. ${ }^{1}$ Menurut data dari Badan Pusat Statistik tahun 2014 menunjukkan

${ }^{1}$ Taufiq, A. \& Maulana, M. F. (2015). Sosialisasi Sampah Organik dan Non Organik Serta Pelatihan Kreasi Sampah. Jurnal Inovasi dan Kewirausahaan, 4 (1), hlm. 68

Vol. 1 No. 2 Oktober 2018

AL - MUDARRIS homepage: http://e-journal.staima-alhikam.ac.id/index.php/almudarris/index 
bahwa Indonesia menghasilkan sampah sekitar 187.2 juta ton per tahun dan menduduki peringkat kedua sebagai negara penghasil sampah terbesar di dunia. ${ }^{2}$

Permasalahan sampah tidak hanya terjadi di dalam rumah tangga, tetapi juga di sekolah. Sebagai sebuah komunitas dengan anggota yang besar, sekolah juga menjadi salah satu tempat penghasil sampah, baik itu sampah organik maupun anorganik. ${ }^{3}$ Tidak hanya itu, kurangnya sosialisasi tentang sampah juga berimbas pada minimnya pemahaman warga sekolah tentang perbedaan anatara sampah organik dan anorganik. Banyak diantara mereka yang belum bisa membedakan sampah organik dan anorganik akibatnya warga sekolah masih sering membuang sampah pada satu tempat yang sama, sehingga sampah menumpuk pada satu tempat saja. Di sisi lain, adapula warga sekolah yang sudah mengerti tentang perbedaan sampah organik dan anorganik namun ketika membuang sampah tersebut mereka seakan tidak peduli dengan program pemilahan sampah, sehingga mereka juga membuangnya dalam satu tempat yang sama.

Kurniasari menjelaskan bahwa kurangnya kepedulian warga sekolah terhadap pengelolaan dan pemanfaatan sampah di sekolah mengakibatkan sampah semakin menumpuk dan hanya berakhir di Tempat Pembuangan Sampah. Padahal beberapa diantaranya masih bisa didaur ulang untuk dimanfaatkan kembali atau bahkan dapat digunakan sebagai media pembelajaran asalkan para warga sekolah tersebut memiliki kepedulian dan kesadaran ekologi yang cukup tinggi. Tanpa disadari, sampah yang menumpuk juga dapat menyebabkan bumi menjadi rusak dan hal ini menandakan bahwa telah terjadi hubungan yang tidak baik antara manusia dengan alam.Oleh karena itu, kesadaran menjaga lingkungan ini menjadi suatu hal yang sangat penting. Penanaman kesadaran menjaga lingkungan melaului pendidikan, diharapkan dapat menjadi sarana sosialisasi dan pemahaman pada warga sekitar tentang lingkungan dan sampah. Pendidikan diharapkan dapat membangun sebuah masyarakat berkelanjutan yang memiliki kesadaran tentang pentingnya kelestarian lingkungan hidup. Kesadaran inilah yang disebut Frijot Capra sebagai eco-literacy. ${ }^{4}$

Eco-literacy atau sering disebut kecerdasan ekologis merupakan kecerdasan yang didasari oleh aspek kognitif atau pemahaman mengenai bagaimana alam menunjang kehidupan semua makhluk hidup. Eco-literacy bersifat kompleks yang didukung oleh kecerdasan intelektual, sosial, emosional dan spiritual. Adanya pengetahuan, kesadaran, dan keterampilan hidup yang selaras dengan kelestarian alam juga semakin mendukung keberhasilan eco-literacy. ${ }^{5}$

Sekolah memiliki peran untuk mengembangkan masyarakat yang sadar lingkungan, dan meningkatkan kecerdasan ekologis ini. Sekolah berperan bukan hanya sebagai tempat belajar tetapi juga memiliki peran penting untuk membantu siswa dalam memahami akibat perilaku manusia di bumi dan menjadi tempat untuk hidup secara

2 Angga \& Djunaidi, Much. (2017). Penentuan Alternatif Lokasi TPA (Tempat Pengelolaan Akhir) Sampah Di Kabupaten Wonogiri Dengan Menggunakan Metode Technique Of Order Preference By Similarity To Ideal Solution (Topsis). (Skripsi, Universitas Muhammadiyah Surakarta, 2017). Diakses dari http://eprints.ums.ac.id/id/eprint/54591

${ }^{3}$ Hisham. (2012). Gambaran Perilaku Siswa Tentang Pengelolaan Sampah Di SMA Negeri 1 Tamalatea. (Skripsi, Universitas Islam Negeri Alauddin, 20172). Diakses dari http://repositori.uinalauddin.ac.id.

${ }^{4}$ Supriatna. Ecopedagogy. (Bandung: PT.Remaja Rosdakarya Offset, 2017), hlm. 24-26, hlm. 313.

${ }^{5}$ Supriatna. Ecopedagogy. (Bandung: PT.Remaja Rosdakarya Offset, 2017), hlm. 24-26, hlm. 313.

Vol. 1 No. 2 Oktober 2018

AL - MUDARRIS homepage: http://e-journal.staima-alhikam.ac.id/index.php/almudarris/index 
berkelanjutan. ${ }^{6}$ Dalam hal ini sekolah berperan untuk memberikan sosialisasi kepada warga masyarakatnya melalui pendidikan berbasis lingkungan serta bagimana cara mengelola dan memanfaatkan sampah dengan baik. Salah satunya adalah pemanfaatan sampah organik dan anorganik sebagai media pembelajaran berbasis eco-literacy yang di terapkan di Sekolah Dasar.

Pemanfaatan lingkungan sekolah serta sampah organik dan anorganik sebagai media pembelajaran, diharapkan mampu meningkatkan peran siswa untuk terlibat dalam peningkatan kesadaran ekologi sejak dini. Karena melalui media pembelajaran, siswa akan dilibatkan pada pengalaman yang melibatkan pikiran, emosi yang terjalin dalam kegiatan yang menyenangkan dan mendorong prakarsa siswa. ${ }^{7}$ Penanaman keadaran lingkungan di tingkat Sekolah Dasar ini, juga diharapkan mampu menumbuhkan kecerdasan ekologi siswa sejak dini sehingga ketika mereka terjun di kehidupan masyarakat mereka dapat mengaplikasikannnya dalam kehidupan sehari-hari.

\section{B. METODE}

Penelitian ini merupakan jenis penelitian kualitatif yang menggunakan metode kajian literatur dengan mengumpulkan dan menggunakan data yang berkaitan dengan penelitian. Sebuah kajian literature menggabungkan dan mempelajari penelitian yang sesuai dengan topic yang dibicarakan tentang apa yang penulis teliti dan tuliskan. ${ }^{8}$ Pendekatan penelitian menggunakan kajian literature ini terdiri dari rangkuman, analisis, sintesis dari beberapa artikel jurnal yang berkaitan dengan pengenalan eco-literacy melalui media pembelajaran yang berasal dari sampah di sekolah.

\section{HASIL DAN PEMBAHASAN}

\section{Pengertian Sampah Organik dan Sampah Anorganik}

Sampah merupakan permasalahan sosial yang tidak hanya ada di pasar maupun pemukiman penduduk melainkan juga menjadi permasalahan di sekolah. Secara umum, sampah di sekolah terdiri dari dua macam, yakni sampah organik dan sampah anorganik. Menurut Taufiq \& Maulana, sampah organik adalah limbah yang bersal dari sisa makhluk hidup (alam) seperti hewan, manusia, tumbuhan yang mengalami pembusukan atau pelapukan. Sampah ini tergolong sampah yang ramah lingkungan karena dapat diurai oleh bakteri secara alami dan berlangsung cepat. Sedangkan sampah anorganik adalah sampah yang berasal dari sisa manusia yang sulit untuk di urai oleh bakteri, sehingga membutuhkan waktu yang cukup lama (hinga ratusan tahun) untuk dapat di uraikan. ${ }^{9}$

Sidik dan Susilowati juga menegaskan bahwa sampah organik atau sampah basah adalah sampah yang berasal dari makhluk hidup, yang mudah terdegradasi, dihancurkan atau terurai oleh alam dengan bantuan mikroorganisme. Salah satu

${ }^{6}$ Ozsoy, S.,Ertepinar, H. \& Saglam, N. (2012). “Can Eco-Schools Improve Elementary School Students’ Environmental Literacy Levels?”. Jurnal AsiaPacific Forum on Science Learning and Teaching, $13(2)$.

${ }^{7}$ Adinugraha, Fajar.(2017). Media Pembelajaran Biologi Berbasis Ecopreneurship. Jurnal Formatif vol.7 (3), hlm. 219-233

${ }^{8}$ Literature Review, https://www.apu.edu Retrieved 04 August, 2018

${ }^{9}$ Taufiq, A. \& Maulana, M. F. (2015). Sosialisasi Sampah Organik dan Non Organik Serta Pelatihan Kreasi Sampah. Jurnal Inovasi dan Kewirausahaan, 4 (1), hlm. 69

Vol. 1 No. 2 Oktober 2018

AL - MUDARRIS homepage: http://e-journal.staima-alhikam.ac.id/index.php/almudarris/index 
contoh sampah organik yang dapat ditemukan di sekolah yaitu daun-daun yang berguguran dari pepohonan. Sedangkan sampah anorganik atau sampah kering adalah sampah yang tidak bisa terdegradasi secara alami, kalaupun bisa terurai pasti membutuhkan waktu yang lama. Contoh sampah anorganik yang ada di lingkungan sekolah antara lain plastik, kaleng, botol, kertas, sedotan dan lain-lain. ${ }^{10}$

\section{Permasalahan Sampah di Sekolah}

Sampah organik dan anorganik tidak hanya ditemukan di lingkungan masyarakat maupun limbah rumah tangga tetapi juga banyak ditemukan di lingkungan sekolah. Di lingkungan sekolah sering ditemukan timbunan sampah anorganik terutama sampah plastik yang cukup mengganggu. Hal ini disebabkan karena pihak sekolah belum menemukan solusi penanganan yang tepat. Keterbatasan pengetahuan dan keterampilan sumberdaya memanfaatkan teknologi tepat guna menjadi kendala pihak sekolah. ${ }^{11}$

Namun, kurangnya kesadaran akan pemilahan dan pengelolaan sampah mengakibatkan sampah menjadi menumpuk dan hanya berakhir di Tempat Pembuangan Sampah saja. Kurangnya kesadaran ekologi ini merupakan salah satu Pekerjaan Rumah terbesar bagi pihak sekolah untuk mengajarkan tentang pentingnya pemanfaatan lingkungan sekitar sebaik mungkin termasuk dalam hal pemanfaatan sampah. Karena tidak menutup kemungkinan bahwasannya para warga sekolah sebenarnya belum paham mengenai perbedaan sampah organik dan anorganik serta bagaimana cara memisahkan dan memanfaatkannya sebagai bentuk penerapan dari 3R yakni Reduce, Reuse dan Recycle atau bahkan sebenarnya mereka sudah paham akan perbedaan sampah organik dan anorganik namun karena pihak sekolah kurang memfasilitasi akan adanya tong sampah organik dan anorganik maupun penjelasan tentang pemanfaatan sampah untuk di daur ulang kembali menjadikan warga sekolah menjadi kurang peka terhadap permasalahan sampah. Sehingga kesadaran ekologi merekapun masih rendah.

\section{Pentingnya Kecerdasan Ekologis di Lingkungan Sekolah}

Permasalahan lingkungan yang terjadi pada saat ini, seperti hutan gundul akibat penebangan pohon tanpa melestarikannya, polusi air dari limbah industri, polusi udara yang berasal dari asap kendaraan, kebakaran hutan, perburuan hewan langka juga merupakan suatu permasalahan yang diakibatkan oleh ulah manusia yang mencerminkan ketidakpeduliannya terhadap lingkungan serta kurangnya kesadaran terhadap pentingnya lingkungan hidup. ${ }^{12}$

Sekolah memiliki peranan penting dalam memperluas jejaring untuk meningkatkan kecerdasan ekologis. Sebagaimana diungkapkan oleh Capra yang menjelaskan bahwa sistem sosial seperti di sekolah akan berpengaruh pada pengalaman belajar anak. Sebab pengalaman belajar dapat di bentuk di kelas

\footnotetext{
${ }^{10}$ Sidik \& Susilowati.(2013). Desain Media Edukasi Animasi Interaktif Cara Pemanfaatan Limbah Sampah Berbasis Macromedia Flash 8. Jurnal Techno Nusa Mandiri Vol. X (1), hlm. 196

${ }^{11}$ Lisdiana, Widiyaningrum, P., \& Nurrohmah, S. (2016). Pengelolaan Sampah Plastik Di Lingkungan Sekolah Adiwiyata. Seminar Nasional 2016; Hasil Penelitian dan Pengabdian Kepada Masyarakat UNMAS, Despansar. Diakses dari http://lppm.unmas.ac.id

${ }^{12}$ Karlina, F., Dedeng, I.N.S., \& Amirudin, A. (2017). Ecoliteracy Siswa SD Dalam Kegiatan Pengelolaan Sampah Melaului Grup Investigation Berbasis Outdoor Study. Jurnal Pendididkan, 2 (7), hlm. 991.

Vol. 1 No. 2 Oktober 2018
}

AL - MUDARRIS homepage: http://e-journal.staima-alhikam.ac.id/index.php/almudarris/index 
melalui sistem pendidikan, ekosistem maupun sistem politik yang sekolah terapkan. ${ }^{13}$

Sekolah menjadi dasar betapa pentingnya penanaman akan kesadaran lingkungan dapat diterapkan di sekolah. Kerjasama antar pihak sekolah dan warga sekolah sangat diperlukan untuk menanamkan pengetahuan hingga adanya perubahan perilaku atau menginternalisasi adanya kecerdasan untuk mengelola lingkungan di sekitarnya. Hal ini bertujuan untuk menemukan inovasi proses internalisasi nilai-nilai ekologis yang akan ditanamkan pada diri siswa sekolah dasar. ${ }^{14}$ Artinya, pengelolaan sampah juga harus menjadi perhatian serius pihak sekolah dengan merancang kegiatan-kegiatan yang sifatnya terencana dan berkesinambungan. Kegiatan-kegiatan tersebut merupakan bagian integral pendidikan di sekolah untuk meningkatkan kesadaran ekologis sejak dini.

Adanya kecerdasan ekologis ini merupakan salah satu upaya untuk mewujudkan masyarakat yang berkelanjutan. Karena selama ini, kita hanya membicarakan tentang lingkungan dan sumber daya alam di sekitarnya yang bisa diwariskan pada anak cucu nanti, namun kita sering lupa untuk mengajarkan tentang bagaimana caranya membangun masyarakat yang berkelanjutan atau sustainable society. ${ }^{15}$

Stone dan Barlow juga menjelaskan bahwa salah satu upaya untuk membangun dunia secara berkelanjutan tidak akan berhasil jika generasi masa depan tidak bekerjasama dengan sistem alam. Dengan kata lain anak-anak harus "peduli terhadap lingkungan hidup atau ecologically literate", agar memiliki dasar ekologi, memahami proses dan ruang lingkup ekologi sehingga siswa akan menjadi lebih cepat tanggap dalam mengahadapi masalah yang terjadi di sekitar lingkungannya. ${ }^{16}$ Siswa yang mendapatkan pendidikan eco-literacy yang baik akan memiliki kecerdasan ekologis yang lebih mendalam tentang pentingnya memahami keterkaitan dan sikap peduli terhadap lingkungan dan sekitarnya, mereka akan lebih peduli terhadap ekologi serta mampu bertindak dan bersikap dengan ekosistem di sekitarnya menggunkan pengetahuan dan perasaan. ${ }^{17}$

Guru mempunyai andil besar dalam upaya untuk memberikan pemahaman bagi siswa akan pentingnya kesadaran lingkungan. Bahkan siswa diharapkan dapat membentuk kepribadian yang baik dan nantinya tercerminkan pada setiap perilaku di kehidupan sehari-hari. Hal tersebut dilakukan dengan cara melibatkan siswa untuk berperan serta menjaga lingkungan sekolah yang sehat dan bersih sehingga

13 Capra, Fritjot. (2007). Sustainable Living, Ecological Literacy, and the Breath of Life. Canadian Journal of Environmental Education, 12, hlm.14.

${ }^{14}$ Purnami, W., Utama, W.G. \& Madu, Fransiska J. (2016). Internalisasi Kesadaran Ekologis Melalui Pengelolaan Sampah di Lingkungan Sekolah Dasar. Prosiding Seminar Nasional Pendidikan Sains (SNPS) 2016. Surakarta: Universitas Sebelas Maret

${ }^{15}$ Capra, Fritjot. (2007). Sustainable Living, Ecological Literacy, and the Breath of Life. Canadian Journal of Environmental Education, 12, hlm.14

${ }^{16}$ Stone, M.K. \& Barlow, Z. Ecological Literacy: Educating Our Children for a Sustainable World.( San Francisco: Sierra Club Books, 2015).

${ }^{17}$ Setiawati, T. (2017). Peningkatan Kecerdasan Ekologis Peserta Didik Dalam Bertransportasi Hemat BBM Melalui Pembelajaran IPS Kontekstual ; PTK di Kelas VII A SMP Negeri 2 Tomo Kabupaten Sumedang Pada Materi Kelangkaan Sumber Daya Alam. (Thesis, Universitas Pendidikan Indonesia, 2017). Diakses dari http://ejournal.upi.edu/index.php/pips/article/view/4713

Vol. 1 No. 2 Oktober 2018

AL - MUDARRIS homepage: http://e-journal.staima-alhikam.ac.id/index.php/almudarris/index 
menciptakan suasana yang membuat nyaman bagi seluruh orang yang berada di lingkungan sekolah. ${ }^{18}$

Berkaitan dengan keterampilan abad ke 21, kesadaran lingkungan merupakan salah satu subyek interdisipliner yang menjadi framework keterampilan yang sesuai dengan permasalahan dan isu saat ini. Kesadaran lingkungan dapat diwujudkan dengan adanya kepedulian terhadap lingkungan dan memahami penggunaan energi dan keberlanjutan sumber daya. ${ }^{19}$

Sesuai dengan kecakapan abad 21, guru juga harus mampu mengimplementasikan strategi pembelajaran sebagai berikut: (1) berpusat pada peserta didik/student centre; (2) mengembangkan kreativitas peserta didik; (3) menciptakan suasana menarik, menyenangkan, dan bermakna; (4) mengembangkan berbagai kemampuan yang bernilai dan bermakna; (5) belajar dengan melakukan yaitu peserta didik berbuat; (6) menitikberatkan pada penggalian, penemuan, dan penciptaan; dan (8) menciptakan pembelajaran dengan pendekatan kontekstual. ${ }^{20}$

\section{Pemanfaatan Sampah Sebagai Media Pembelajaran}

Kaitan antara keterampilan abad 21 dengan pengelolaan sampah ini adalah sebelum memanfaatkan sampah menjadi media pembelajaran yang mengasah kreativitas guru dan peserta didik. Menurut Karlina, siswa terlebih dahuluharus mengetahui perbedaan anatara sampah organik dan anorganik melalui kegiatan pembelajaran dengan praktik pemilahan sampah organik dan anorganik baik secara individu maupun kelompok.Hal ini juga dilakukan untuk menanggulangi penumpulan sampah dan memiliki karakter cinta akan kebersihan. ${ }^{21}$ Setelah mereka paham tentang sampah organik dan anorganik maka pembelajaran dapat dilakukan dengan memanfaatkannya secara kreatif dan inovatif sebagai media pembelajaran. Salah satu komponen pendidikan yang harus dilaksanakan oleh seorang guru untuk mewujudkan keberhasilan pelaksanaan strategi pembelajaran tersebut adalah dengan adanya pengadaan media pembelajaran.

Dengan adanya media pembelajaran guru dapat menyampaikan materi dengan maksimal dan efesien kepada siswa, apalagi pada pendidikan tingkat Sekolah Dasar yang mayoritas siswanya terdiri dari anak yang berusia 6-11 tahun, maka dibutuhkanlah sebuah media yang dapat menarik prestasi belajar mereka untuk tercapainya tujuan pembelajaran. ${ }^{22}$

Penggunakan media pembelajaran dalam kegiatan belajar mengajar akan meningkatkan motivasi dan membantu mempermudah pemahaman peserta didik terhadap materi sehingga menciptakan pembelajaran yang bermakna. Seorang guru harus memiliki kemampuan dalam menciptakan media pembelajaran yang inovatif sehingga dapat meningkatkan pemahaman dan motivasi belajar peserta didik.

${ }^{18}$ Karlina, F., Dedeng, I.N.S., \& Amirudin, A. (2017). Ecoliteracy Siswa SD Dalam Kegiatan Pengelolaan Sampah Melaului Grup Investigation Berbasis Outdoor Study. Jurnal Pendididkan, 2 (7), hlm. 992.

${ }^{19}$ Setiawati, T. (2017). Peningkatan Kecerdasan Ekologis Peserta Didik Dalam Bertransportasi Hemat BBM Melalui Pembelajaran IPS Kontekstual ; PTK di Kelas VII A SMP Negeri 2 Tomo Kabupaten Sumedang Pada Materi Kelangkaan Sumber Daya Alam. (Thesis, Universitas Pendidikan Indonesia, 2017). Diakses dari http://ejournal.upi.edu/index.php/pips/article/view/4713

${ }^{20}$ Astutik, P.P. (2017). Penguatan Pendidikan Karakter Untuk Menghadapi Tantangan Abad 21.

Seminar Nasioanal PGSD UNIKAMA vol. 1, Desember 2017. Diakses dari https://semnas.unikama.ac.id

${ }^{21} 21$ Supriatna. Ecopedagogy. (Bandung: PT.Remaja Rosdakarya Offset, 2017), hlm.317

${ }^{22}$ Ma'ruf, A. \& Mahmudiyah, L. (2016). Penggunaan Media Limbah Bungkus Sabun Mandi Untuk Meningkatkan Prestasi Belajar Pendidikan Agama Islam Di SDN Sumberanyar 1 Pasuruan. Jurnal Studi Islam, 1, (2).

Vol. 1 No. 2 Oktober 2018

AL - MUDARRIS homepage: http://e-journal.staima-alhikam.ac.id/index.php/almudarris/index 
Media pembelajaran sebagai alat bantu dalam kegiatan pembelajaran dapat dikembangkan secara sederhana dari beberapa sampah yang ada di lingkungan sekitar. $^{23}$

Menurut Palmer \& Neal, salah satu upaya yang bisa dilakukan untuk memperbaiki lingkungan sekolah dalam mengatasi permasalahan sampah adalah dengan bekerja sama mendaur ulang sampah oleh seluruh pihak sekolah. ${ }^{24}$ Fakhriyah, Wanabuliandri \& Ardianti, juga menjelaskan bahwa selain berguna sebagai media pembelajaran, pemanfaatan sampah juga mampu mengurangi produksi sampah. Produksi sampah yang berlebihan tanpa diimbangi dengan proses pengolahan yang baik akan memberikan dampak buruk terhadap lingkungan. ${ }^{25}$

Pemanfaatan sampah plastik dan kertas menjadi media pembelajaran di sekolah dapat dilakukan oleh seorang guru guna menciptakan pembelajaran yang inovatif. Selain itu pembuatan media pembelajaran dengan memanfaatkan sampah plastik dan kertas dapat meningkatkan kreativitas dan rasa kepedulian terhadap lingkungan. Dalam pembuatan media pembelajaran yang berasal dari sampah organik dan anorganik membutuhkan adanya keterampilan dalam belajar dan berinovasi pada abad ke-21, yakni keterampilan berkreasi dan berinovasi (creativity and innovation). Keterampilan ini merupakan keterampilan yang menerapkan imaginasi dan penemuan. Kreativitas dan inovasi dapat dipupuk melalui lingkungan belajar yang menumbuhkan pertanyaan, kesabaran, keterbukaan untuk ide-ide yang baru, serta belajar dari kesalahan dan kegagalan yang dilakukan. Kreativitas dan inovasi dapat dikembangkan seperti layaknya keterampilan lain melalui latihan dari waktu ke waktu. ${ }^{26}$

Pembuatan media pembelajaran ini bukanlah suatu hal yang mudah, jika tidak diasah dan dibiasakan di sekolah karena membutuhkan adanya kreativitas yang cukup tinggi agar mengahasilkan media pembelajaran yang optimal. Piirto menjelaskan bahwa untuk menerapkan kreativitas dalam keterampilan abad ke-21, diperlukan adanya lima sikap inti diantaranya; 1.) sikap inti dalam disiplin diri dengan melakukan pekerjaan yang kreatif termasuk adanya motivasi, 2.) sikap inti dalam keterbukaan terhadap pengalaman, 3.) sikap inti untuk berani pengambilan risiko, 4.) sikap inti dari toleransi untuk ambiguitas, 5.) sikap inti dalam kepercayaan kelompok. Termasuk dalam pembuatan media pembelajaran sikap inti ini harus dijadikan sebagai acuan dalam menerapkan kreativitas. Salah satunya adalah core attitude of openess experiences atau sikap inti dari keterbukaan untuk pengalaman. $^{27}$

${ }^{23}$ Edison. (2015). Pembelajaran Pembelajaran Konsep Reduce, Reuse, Recycle Dalam Mata Pelajaran Ilmu Pengetahuan Sosial Dengan Model Picture And Picture Untuk Meningkatkan Eco-literacy Peserta Didik; Penelitian Tindakan Di Kelas VII Sunan Gresik SMP Islam Insan Rabbany Kota Tangerang Selatan. (Thesis, Universitas Pendidikan Indonesia, 2015). Diakses dari http://repository.upi.edu/id/eprint/18721

${ }^{24}$ Fakhriani, F., Winabuliandri, S., Ardianti, S.D. (2016). Pendampingan Pemanfaatan Sampah Plastik Dan Kertas Untuk Media Pembelajaran Inovatif Bagi Guru Di SDN 5 Bae, Kudus. Jurnal Pengabdian Pada Masyarakat, 1, (1), hlm. 50.

${ }^{25}{ }^{18}$ Fakhriani, F., Winabuliandri, S., Ardianti, S.D. (2016). Pendampingan Pemanfaatan Sampah Plastik Dan Kertas Untuk Media Pembelajaran Inovatif Bagi Guru Di SDN 5 Bae, Kudus. Jurnal Pengabdian Pada Masyarakat, 1, (1), hlm. 50.

${ }^{26}$ Triling, B. \& Fadel. C21 ${ }^{\text {st }}$ Century Skills; Learning For Life In Our Times. San (Fransisco: Jossey-Bass A Wiley Imprint, 2009, p.57-58).

${ }^{27}$ Piirto, J. (2017). Creativity for $21^{\text {st }}$ Century Skills; How to Embed Creativity into Curriculum. (Ohio: Sense Publisher, 2017, p.13-18).

Vol. 1 No. 2 Oktober 2018

AL - MUDARRIS homepage: http://e-journal.staima-alhikam.ac.id/index.php/almudarris/index 
Keterbukaan disini maksudnya adalah membuka wawasan orang-orang tentang satu hal yang dulunya dianggap kecil atau remeh ternyata melalui kreativitas hal kecil tersebut dapat diubah menjadi sesuatu yang tidak pernah terlintas di benak orang lain sebelumnya. Misalnya; ketika menjumpai benda berupa sedotan, kebanyakan orang berpikir bahwa sedotan hanya digunakn sebagai alat bantu untuk minum. Tetapi jika orang lain ada yang memiliki keterampilan dalam berkreasi, dia tidak hanya memikirkan bahwa sedotan merupakan alat bantu untuk minum saja tetapi dapat juga digunakan untuk membuat ronce, bunga plastik, kolase dan lain-lain sebagai media pembelajaran yang dapat meningkatkan kreativitas dan motivasi pada siswa.

Dalam hal ini, media pembelajaran dibuat dengan memanfaatkan lingkungan sekolah sebagai sumber belajar. Setelah mereka paham tentang konsep sampah organik dan anorganik, para siswa diberikan kesempatan untuk mencarinya di lingkungan sekolah ataupun membawanya dari rumah. Kemudian mereka akan diajarkan untuk membuat media pembelajaran dengan bantuan guru. Media pembelajarn yang dibuat, diharapkan tidak hanya berfokus pada materi mata pelajaran Seni Budaya dan Prakarya saja melainkan juga melibatkan materi mata pelajaran yang lainnya juga seperti IPA, IPS, Bahasa Indonesia karena saat ini pemerintah Indonesia mulai gencar untuk menerapkan kurikulum 2013 dengan menggunakan pembelajaran terpadu yang memadukan beberapa mata pelajaran

Media pembelajarn yang dibuat, diharapkan tidak hanya berfokus pada materi mata pelajaran Seni Budaya dan Prakarya saja melainkan juga melibatkan materi mata pelajaran yang lainnya juga seperti IPA, IPS, Bahasa Indonesia karena saat ini pemerintah Indonesia mulai gencar untuk menerapkan kurikulum 2013 dengan menggunakan pembelajaran terpadu yang memadukan beberapa mata pelajaran. Hal ini menjadi tantangan tersendiri untuk mengembangkan media pembelajaran yang memanfaatkan sampah dan lingkungan sekitar sebab mindset masyarakat selama ini adalah media pembelajaran itu hanya untuk pelajaran keterampilan tangan atau prakarya saja. Padahal jika guru dan siswa mau bekerjasama untuk membuat media pembelajaran dari bahan bekas, media pemelajaran tersebut dapat digunakan untuk beberapa mata pelajaran yang lain asalkan tema atau materi yang akan disampaikan memiliki keterkaitan antar satu dengan yang lain.

Beberapa contoh media pembelajaran yang dapat dibuat dari sampah organik dan anorganik di Sekolah Dasar di bawah ini merupakan contoh media pembelajaran yang dapat diterapkan di Sekolah Dasar antara lain:

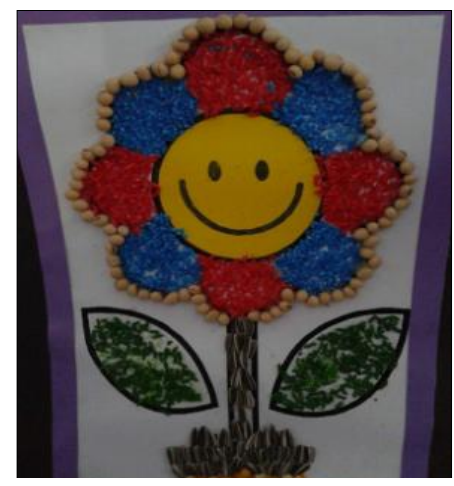

\section{Materi SBdP kelas II;}

Karya seni kolase menggunakan bahan alam dan barang bekas

\section{$\underline{\text { Media; }}$}

Kolase dari biji-bijian yang sudah tidak digunakan (jagung, kedelai, kuaci, beras)

(Sumber: Dokumen Pribadi)

Vol. 1 No. 2 Oktober 2018

AL - MUDARRIS homepage: http://e-journal.staima-alhikam.ac.id/index.php/almudarris/index 


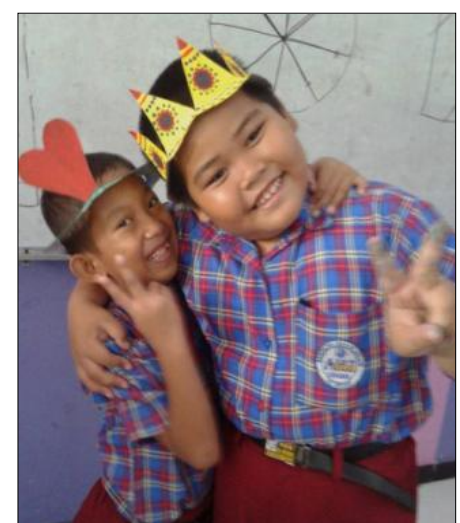

(Sumber: Dokumen Pribadi)

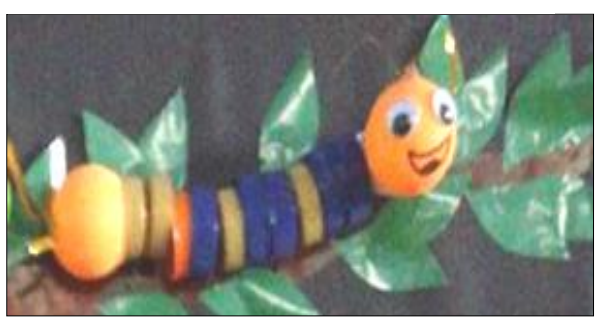

(Sumber: Dokumen Pribadi )

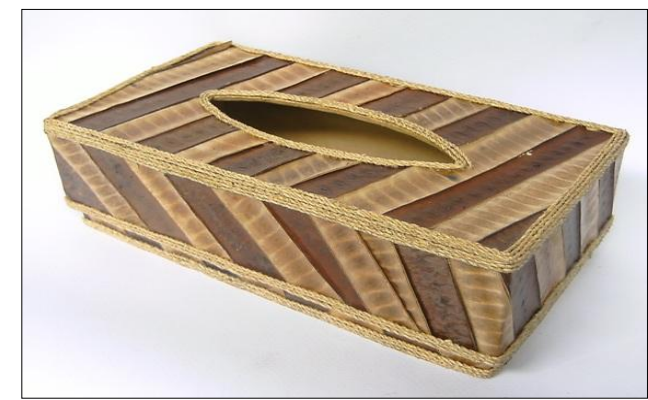

\section{Materi IPA kelas V;}

Mendaur Ulang Sampah

\section{Media;}

Kotak Tissue dari karton manila dan bahan alam seperti lamtoro kering dan pelepah pisang kering

\section{(Sumber: https://www.rumahkreative.id)}

Pembuatan media pembelajaran dengan memanfaatkan sampah organik dan anorganik ini tidak akan bisa berjalan dengan baik tanpa adaanya dukngan dan kerjasama antara pihak sekolah, guru, siswa dan orang tua. Dengan demikian, untuk memenuhi keterampilan abad ke-21 guru dapat mengajarkan kemampuan untuk berkreasi dan berinovasi melalui media pembelajaran dan bekerjasama dengan pihak sekolah maupun orang tua. Media pembelajaran yang kreatif dan inovatif adalah media pembelajaran yang mampu menyampaikan materi dengan baik kepada siswa sehingga mewujudkan pembelajaran yang bermakna dengan memanfaatkan barang-barang disekitar. Salah satunya adalah pemanfaatan sampah organik dan sampah anorganik yang ada di sekolah untuk dijadikan sebagai media pembelajaran sekaligus melatih siswa untuk berkreasi dan berinovasi menggunakan

Vol. 1 No. 2 Oktober 2018

AL - MUDARRIS homepage: http://e-journal.staima-alhikam.ac.id/index.php/almudarris/index 
bahan alam. Pembelajaran yang bermakna juga dapat terwujud dengan melibatkan siswa dalam proses pembelajaran dengan melibatkan mereka pada lingkungan sekitar. Melalui kegiatan ini siswa akan mendapat pengalaman secara langsung sekaligus dapat berkolaborasi dengan guru untuk membuat media pembelajaran yang inovatif dari sampah yang mereka kumpulkan. Sehingga, terwujudlah kreativitas dan inovasi dalam pembuatan media pembelajaran yang sekaligus meningkatkan kepedulian terhadap lingkungan di sekitar serta meningkatkan kecerdasan ekologi siswa. Dalam mewujudkan kreativitas tersebut dibutuhkan komitmen yang besar antara guru dan siswa untuk saling berkolaborasi dalam mewujudkan kreativitas sehingga pembelajaran dapat berjalan secara aktif dan menyenangkan.

\section{KESIMPULAN}

Permasalahan sampah yang selama ini menjadi permasalahan sosial yang cukup besar di Indonesia sebenarnya dapat berkurang asalkan ada kerjasama dalam kehidupan masyarakat. Salah satunya adalah kerjasama dalam pengelolaan sampah di lingkungan sekolah. Dalam hal ini, keterlibatan antara pihak sekolah, baik itu guru, siswa dan orang tua beserta masyarakat di sekitar. Menjadi sangat penting dalam memanfaatkan sampah. Karena bagaimanapun juga sampah di sekolah juga menyumbang penumpukan sampah yang cukup besar jika tidak diimbangi dengan penerapan $3 \mathrm{R}$ yakni Reduce, Reuse dan Recycle. Kurangnya sosialisasi tentang sampah juga berimbas pada minimnya pemahaman warga sekolah tentang perbedaan antara sampah organik dan anorganik. Banyak diantara mereka yang belum bisa membedakan sampah organik dan anorganik akibatnya warga sekolah masih sering membuang sampah pada satu tempat yang sama, sehingga sampah menumpuk pada satu tempat saja. Di sisi lain, adapula warga sekolah yang sudah mengerti tentang perbedaan sampah organik dan anorganik namun ketika membuang sampah tersebut mereka seakan tidak peduli dengan program pemilahan sampah, sehingga mereka juga membuangnya dalam satu tempat yang sama. Kurangnya kepedulian warga sekolah terhadap pengelolaan dan pemanfaatan sampah di sekolah mengakibatkan sampah semakin menumpuk dan hanya berakhir di Tempat Pembuangan Sampah.

Dengan adanya tuntutan abad ke-21 untuk menjadi masyarakat yang mampu berpikir kreatif dan memecahkan masalah memaksa kita untuk memikirkan bagaimana langkah yang tepat untuk mengelola sampah organik dan anorganik di lingkungan sekolah. Salah satu caranya adalah dengan memanfatkan sampah tersebut sebagai media pembelajaran. Melalui media pelajaran ini, diharapkan siswa tidak hanya memahami akan pentingnya pemanfaatan sampah dalam pengelolaan lingkungan sekitar tetapi juga melatih kecerdasan ekologis siswa untuk lebih peduli terhadap lingkungan di sekitarnya. Sehingga, setelah ini mereka akan lebih paham tentang konsep cinta lingkungan, pengertian dan pengelolaan sampah organik dan anorganik dan semakin peduli dengan lingkungannya.

Pembuatan media pembelajaran dengan memanfaatkan sampah organik dan anorganik ini tidak akan bisa berjalan dengan baik tanpa adaanya dukngan dan kerjasama antara pihak sekolah, guru, siswa dan orang tua. Oleh karena itu, kerja sama sangat diperlukan dalam upaya mensukseskan program kepedulian terhadap lingkungan ini dengan memanfaatkan sampah organik dan anorganik senagaimedia pembelajaran. Sehingga, selain mampu melatih kreativitas siswa dalam membuat media pembelajaran dengan memanfatkan sampah siswa juga mampu menginternalisasi sikap peduli

Vol. 1 No. 2 Oktober 2018

AL - MUDARRIS homepage: http://e-journal.staima-alhikam.ac.id/index.php/almudarris/index 
terhadap lingkungannya bukan hanya di sekolah melainkan juga di lingkungan sekitar tempat tinggalnya.

\section{E. DAFTAR PUSTAKA}

Adinugraha, Fajar.(2017). Media Pembelajaran Biologi Berbasis Ecopreneurship. Jurnal Formatif vol.7 (3), hlm. 219-233.

Angga \& Djunaidi, Much. (2017). Penentuan Alternatif Lokasi TPA (Tempat Pengelolaan Akhir) Sampah Di Kabupaten Wonogiri Dengan Menggunakan Metode Technique Of Order Preference By Similarity To Ideal Solution (Topsis). (Skripsi, Universitas Muhammadiyah Surakarta, 2017). Diakses darinhttp://eprints.ums.ac.id/id/eprint/54591.

Astutik, P.P. (2017). Penguatan Pendidikan Karakter Untuk Menghadapi Tantangan Abad 21. Seminar Nasioanal PGSD UNIKAMA vol. 1, Desember 2017. Diakses dari https://semnas.unikama.ac.id

Capra, Fritjot. (2007). Sustainable Living, Ecological Literacy, and the Breath of Life. Canadian Journal of Environmental Education, 12, hlm.9-18.

Edison. (2015). Pembelajaran Pembelajaran Konsep Reduce, Reuse, Recycle Dalam Mata Pelajaran Ilmu Pengetahuan Sosial Dengan Model Picture And Picture Untuk Meningkatkan Eco-literacy Peserta Didik; Penelitian Tindakan Di Kelas VII Sunan Gresik SMP Islam Insan Rabbany Kota Tangerang Selatan. (Thesis, Universitas Pendidikan Indonesia, 2015). Diakses dari http://repository.upi.edu/id/eprint/18721

Fakhriani, F., Winabuliandri, S., Ardianti, S.D. (2016). Pendampingan Pemanfaatan Sampah Plastik Dan Kertas Untuk Media Pembelajaran Inovatif Bagi Guru Di SDN 5 Bae, Kudus. Jurnal Pengabdian Pada Masyarakat, 1, (1), hlm. 48-55.

Hisham. (2012). Gambaran Perilaku Siswa Tentang Pengelolaan Sampah Di SMA Negeri 1 Tamalatea. (Skripsi, Universitas Islam Negeri Alauddin, 20172). Diakses dari http://repositori.uin-alauddin.ac.id.

Karlina, F., Dedeng, I.N.S., \& Amirudin, A. (2017). Eco-literacy Siswa SD Dalam Kegiatan Pengelolaan Sampah Melaului Grup Investigation Berbasis Outdoor Study. Jurnal Pendididkan, 2 (7), hlm. 991-1002.

Literature Review, https://www.apu.edu Retrieved 04 August, 2018.

Lisdiana, Widiyaningrum, P., \& Nurrohmah, S. (2016). Pengelolaan Sampah Plastik Di Lingkungan Sekolah Adiwiyata. Seminar Nasional 2016; Hasil Penelitian dan Pengabdian Kepada Masyarakat UNMAS, Despansar. Diakses dari http://lppm.unmas.ac.id

Ma'ruf, A. \& Mahmudiyah, L. (2016). Penggunaan Media Limbah Bungkus Sabun Mandi Untuk Meningkatkan Prestasi Belajar Pendidikan Agama Islam Di SDN Sumberanyar 1 Pasuruan. Jurnal Studi Islam, 1, (2).

Ozsoy, S., Ertepinar, H. \& Saglam, N. (2012). "Can Eco-Schools Improve Elementary School Students' Environmental Literacy Levels?”. Jurnal AsiaPacific Forum on Science Learning and Teaching, 13 (2).

Piirto, J. (2017). Creativity for $21^{\text {st }}$ Century Skills; How to Embed Creativity into Curriculum. Ohio: Sense Publisher.

Purnami, W., Utama, W.G. \& Madu, Fransiska J. (2016). Internalisasi Kesadaran Ekologis Melalui Pengelolaan Sampah di Lingkungan Sekolah Dasar.

Vol. 1 No. 2 Oktober 2018

AL - MUDARRIS homepage: http://e-journal.staima-alhikam.ac.id/index.php/almudarris/index 
Prosiding Seminar Nasional Pendidikan Sains (SNPS) 2016. Surakarta: Universitas Sebelas Maret.

Setiawati, T. (2017). Peningkatan Kecerdasan Ekologis Peserta Didik Dalam Bertransportasi Hemat BBM Melalui Pembelajaran IPS Kontekstual ; PTK di Kelas VII A SMP Negeri 2 Tomo Kabupaten Sumedang Pada Materi Kelangkaan Sumber Daya Alam. (Thesis, Universitas Pendidikan Indonesia, 2017). Diakses dari http://ejournal.upi.edu/index.php/pips/article/view/4713

Sidik \& Susilowati.(2013). Desain Media Edukasi Animasi Interaktif Cara Pemanfaatan Limbah Sampah Berbasis Macromedia Flash 8. Jurnal Techno Nusa Mandiri Vol. X (1), hlm. 195-206.

Stone, M.K. \& Barlow, Z. (2015). Ecological Literacy: Educating Our Children for a Sustainable World. San Francisco: Sierra Club Books.

Supriatna. (2017). Ecopedagogy. Bandung: PT.Remaja Rosdakarya Offset.

Taufiq, A. \& Maulana, M. F. (2015). Sosialisasi Sampah Organik dan Non Organik Serta Pelatihan Kreasi Sampah. Jurnal Inovasi dan Kewirausahaan, 4 (1), hlm. 68-73.

Triling, B. \& Fadel, C. (2009). $21^{\text {st }}$ Century Skills; Learning For Life In Our Times.

Sumber lain: San Fransisco: Jossey-Bass A Wiley Imprint.

Buku Tematik Terpadu Kurikulum 2013,Tema3:Peduli Terhadap Makhluk Hidup Untuk SD/MI Kelas IV. Kementrian Pendidikan dan Kebudayaan Republik Indonesia 2014.

https://www.rumahkreative.id 